\title{
New Methods for the Site-Selective Placement of Peptides on a Microelectrode Array: Probing VEGF - v107 Binding as Proof of Concept
}

\author{
Matthew D. Graaf, ${ }^{\mathrm{a}}$ Bernadette V. Marquez, ${ }^{\mathrm{b}}$ Nai-Hua Yeh, ${ }^{\mathrm{a}}$ Suzanne E. Lapi, ${ }^{\mathrm{a}, \mathrm{b} *}$ and \\ Kevin D. Moeller ${ }^{\text {** }}$ \\ ${ }^{a}$ Department of Chemistry, Washington University in St. Louis, St. Louis, MO, USA 63130 \\ ${ }^{b}$ Department of Radiology, Washington University in St. Louis, St. Louis, MO, USA 63110
}

\section{SUPPORTING INFORMATION}

Synthesis of azido-cysteine-methylester:

1)

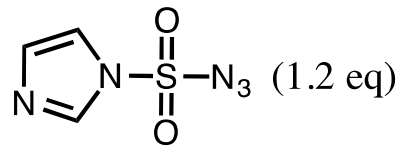<smiles>N[C@@H](C[Sn])C(=O)O</smiles>

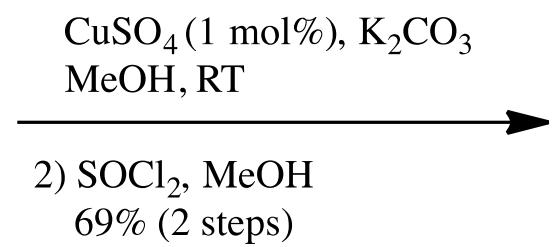<smiles>COC(=O)[C@H](C[Sn])N=[N+]=[N-]</smiles>

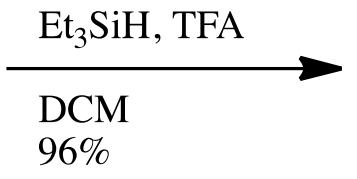<smiles>COC(=O)[C@H](CS)N=[N+]=[N-]</smiles>

$\mathrm{N}_{3}$-Cys(Trt)-OMe<smiles>COC(=O)[C@H](C[Sn])N=[N+]=[N-]</smiles>

In a $25 \mathrm{~mL}$, flame-dried round bottom flask, $726 \mathrm{mg}(2.0 \mathrm{mmol}) \mathrm{H}-\mathrm{Cys}(\mathrm{Trt})-\mathrm{OH}, 5 \mathrm{mg}(0.020$ $\mathrm{mmol}) \mathrm{CuSO}_{4}$, and $552 \mathrm{mg}(4 \mathrm{mmol}) \mathrm{K}_{2} \mathrm{CO}_{3}$ were dissolved in $10 \mathrm{~mL}$ anhydrous methanol. The imidazole- 
sulfonyl-azide (HCL) diazotransfer agent $(0.5 \mathrm{~g}, 2.4 \mathrm{mmol})$ was slowly added to the solution and allowed to stir overnight while open to the atmosphere. Upon completion, the methanol was removed and the crude mixture was suspended in $\mathrm{H}_{2} \mathrm{O}$ before being acidified with concentrated $\mathrm{HCl}$. The acidified mixture was extracted with ethyl acetate. All organic layers were dried with $\mathrm{MgSO}_{4}$, filtered and concentrated in vacuo.

Esterification of the azido-cysteine was performed without further purification. The mixture was dissolved in $5.0 \mathrm{~mL}$ methanol and $0.05 \mathrm{~mL}$ thionyl chloride was added to the solution, being allowed to stir overnight. The crude mixture was purified via column chromatography using 9:1 hexanes:ethyl ether obtaining the product in a $69 \%$ yield $(558 \mathrm{mg}$, MW $=403.5 \mathrm{~g} / \mathrm{mol}) .{ }^{1} \mathrm{H}-\mathrm{NMR}\left(300 \mathrm{MHz} ; \mathrm{CDCl}_{3}\right): \delta 7.47$ $7.43(\mathrm{~m}, 6 \mathrm{H}), 7.33-7.21(\mathrm{~m}, 9 \mathrm{H}), 3.71(\mathrm{~s}, 3 \mathrm{H}), 3.22$ (dd, $J=8.1,5.9 \mathrm{~Hz}, 1 \mathrm{H}), 2.71$ (dd, $J=13.4,5.9 \mathrm{~Hz}$, $1 \mathrm{H}), 2.60-2.53(\mathrm{dd}, J=13.4,8.1 \mathrm{~Hz}, 1 \mathrm{H}) ;{ }^{13} \mathrm{C} \mathrm{NMR}\left(75 \mathrm{MHz} ; \mathrm{CDCl}_{3}\right): \delta 169.3,144.2,129.5,128.1,126.9$, 67.3, 61.3, 52.7, 33.2; IR (KBr) 3467, 3055, 2950, 2505, 2107, 1745, 1593, 1487, 1443, 1206, $740 \mathrm{~cm}^{-1}$; HRESI MS m/z [M+Na $]$ Found: 426.1244, Calculated: 426.1254

\section{$\mathrm{N}_{3}$-Cys-OMe}<smiles>COC(=O)[C@H](CS)N=[N+]=[N-]</smiles>

The trityl deprotection of the azido-cysteine was in a flamed-dried $25 \mathrm{~mL}$ round bottom flask. 530 mg N $\mathrm{N}_{3}$-Cys(Trt)-OMe (1.31 mmol) was dissolved in $5 \mathrm{~mL}$ dichloromethane. $0.5 \mathrm{~mL}$ TFA and $0.3 \mathrm{~mL}$ $\mathrm{Et}_{3} \mathrm{SiH}$ were added to the flask and allowed to stir overnight. Upon completion, the mixture was diluted with DCM and concentrated in vacuo. The crude mixture was purified via column chromatography using 9:1 hexanes:ethyl ether. The deprotected product was obtained in a 96\% yield $(203 \mathrm{mg}, \mathrm{MW}=161.18$ $\mathrm{g} / \mathrm{mol}) .{ }^{1} \mathrm{H}-\mathrm{NMR}\left(300 \mathrm{MHz} ; \mathrm{CDCl}_{3}\right): \delta 4.25(\mathrm{dd}, J=8.0,5.3 \mathrm{~Hz}, 1 \mathrm{H}), 3.82-3.81(\mathrm{~s}, 3 \mathrm{H}), 3.21(\mathrm{dd}, J=14.0$, $5.3 \mathrm{~Hz}, 1 \mathrm{H}), 3.00(\mathrm{dd}, J=14.0,8.1 \mathrm{~Hz}, 1 \mathrm{H}), 1.25-1.23(\mathrm{~s}, 1 \mathrm{H}) ;{ }^{13} \mathrm{C} \mathrm{NMR}\left(126 \mathrm{MHz} ; \mathrm{CDCl}_{3}\right): \delta 164.1,55.8$, 47.9, 34.8 ppm; IR (KBr) 3365, 2952, 2920, 2493, 2115, 1741, 1435, 1246, 1205, $1004 \mathrm{~cm}^{-1}$; HRESI MS $\mathrm{m} / \mathrm{z}\left[\mathrm{M}+\mathrm{Na}^{+}\right]$Found: 184.0172 , Calculated: 184.0159

Synthesis of 1-(pent-4-yn-1-yl)pyrene:
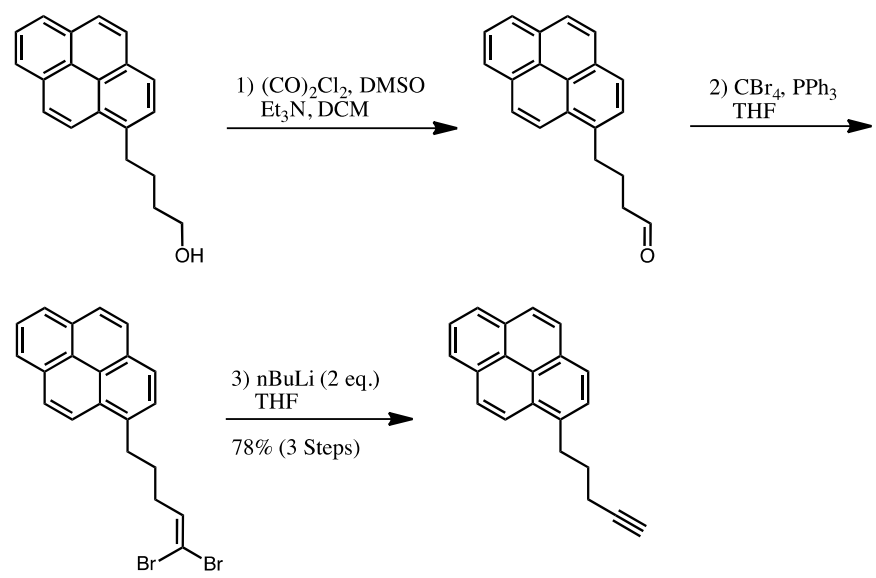

In a flame-dried, $50 \mathrm{~mL}$ round bottom flask, $0.11 \mathrm{~mL}$ oxalyl chloride was dissolved in $3 \mathrm{~mL}$ dichloromethane and cooled to $-78^{\circ} \mathrm{C} .0 .2 \mathrm{~mL}$ dimethylsulfoxide was added to the flask and stirred for two 
minutes. 1-pyrenebutanol (300 $\mathrm{mg}, 1.09 \mathrm{mmol})$ was dissolved in $2 \mathrm{~mL} \mathrm{DCM}$ and added slowly to the reaction solution and stirred for 15 minutes. $1 \mathrm{~mL}$ triethylamine was added and stirred for 5 minutes before warming to room temperature. The solution was quenched with water and extracted with DCM. The organic layers were dried over $\mathrm{MgSO}_{4}$, filtered and rotavapped. No further purification was performed.

In a flame-dried, $50 \mathrm{~mL}$ round bottom flask, $362 \mathrm{mg}$ carbon tetrabromide and $571 \mathrm{mg}$ triphenylphosphine were dissolved in $10 \mathrm{~mL}$ DCM. The crude aldehyde from the previous Swern oxidation was dissolved in DCM, slowly added to the reaction solution and stirred for one hour. Upon completion, the reaction was quenched with water and extracted with DCM. The combined organic layers were dried over $\mathrm{MgSO}_{4}$, filtered and concentrated in vacuo. No further purification was performed.

The final elimination/dehalogenation step was performed on the Wittig crude. The dibromoalkene product was dissolved in $10 \mathrm{~mL}$ THF. Two equivalents of $\mathrm{nBuLi}(1.6 \mathrm{M}$ solution in hexanes) was slowly added to the flask and stirred for 10 minutes. The reaction was quenched with water and extracted with DCM. The organic layers were dried over $\mathrm{MgSO}_{4}$, filtered and rotavapped. The product was purified via column chromatography using 95:5 hexanes:ethyl ether as the eluent. The pyrene-labeled alkyne was obtained in a $78 \%$ yield over the three steps $(228 \mathrm{mg}$, MW $=268.36 \mathrm{~g} / \mathrm{mol}) .{ }^{1} \mathrm{H}-\mathrm{NMR}\left(300 \mathrm{MHz} ; \mathrm{CDCl}_{3}\right)$ : $\delta 8.31(\mathrm{~d}, J=9.3 \mathrm{~Hz}, 1 \mathrm{H}), 8.15(\mathrm{dd}, J=17.2,7.5 \mathrm{~Hz}, 4 \mathrm{H}), 8.06-8.00(\mathrm{~m}, 3 \mathrm{H}), 7.90(\mathrm{~d}, J=7.8 \mathrm{~Hz}, 1 \mathrm{H}), 3.49$ $(\mathrm{t}, J=7.6 \mathrm{~Hz}, 2 \mathrm{H}), 2.34(\mathrm{td}, J=6.9,2.5 \mathrm{~Hz}, 2 \mathrm{H}), 2.15-2.05(\mathrm{~m}, 3 \mathrm{H}) \mathrm{ppm} ;{ }^{13} \mathrm{C} \mathrm{NMR}\left(75 \mathrm{MHz} ; \mathrm{CDCl}_{3}\right)$ : $\delta 135.8,131.4,130.9,130.0,128.7,127.51,127.37,127.33,126.7,125.8,125.01,124.91,124.81,124.75$, 123.3, 84.3, 69.1, 32.2, 30.3, 18.3 ppm; IR (KBr) 3509, 3296, 3037, 2939, 2113, 1918, 1648, 1601, 1456, 1181, $637 \mathrm{~cm}^{-1}$; GC-HRMS m/z [M ${ }^{+}$Found: 268.1217, Calculated: 268.1252.

\section{Solution Phase Coupling Experiment (Text, Scheme 6):}

A $100 \mathrm{~mL}$ round bottom flask was charged with $5.45 \mathrm{~g}(30 \mathrm{mmol})$ cupric acetate, $0.6 \mathrm{~g}(4 \mathrm{mmol})$ 4vinylphenylboronic acid, $0.6 \mathrm{~g}$ activated $4 \AA$ molecular sieves, $0.6 \mathrm{~mL}$ (4 mmole) triethylamine, and $30 \mathrm{~mL}$ anhydrous dichloromethane. After stirring for 1 hour, $0.22 \mathrm{~mL}(2 \mathrm{mmol})$ phenylacetylene (dissolved in 10 $\mathrm{mL}$ anhydrous dichloromethane) was slowly added to the flask. The solution was then stirred under air at room temperature for 48 hours. The reaction was quenched with ethylenediaminetetraacetic acid solution and then acidified to $\mathrm{pH} 3$ with $1.5 \mathrm{~N} \mathrm{HCl}$. The reaction was extracted with ethyl acetate $(3 \mathrm{x} 20 \mathrm{~mL})$. The organic layers were dried with $\mathrm{MgSO}_{4}$, filtered, and concentrated in vacuo. The crude reaction was passed through a chromatography column using hexane eluent to afford a mixture of three known compounds that could not be easily separated but could be readily identified in the mixture by both proton NMR and mass spectrometry. The yield of each product was determined by integration of the $\mathrm{H}^{1}$-NMR spectroscopy after the addition of 1,3,5-trimethoxybenzene as an internal standard. The reaction afforded $11 \%$ yield of 4phenylethynyl styrene, $85 \%$ yield of 1,4-diphenyldiacetylene, and $22 \%$ yield of bis(4-vinylphenyl) ether. The yields of the 4-phenylethynyl styrene and 1,4-diphenyldiacetylene were calculated based on the phenylacetylene starting material that was used as the limiting reagent. The yield of the bis(4-vinylphenyl) ether was based on the amount of vinylboronic acid used since it was derived exclusively from that substrate and water.

\section{Homology Modeling for the Human and Murine VEGF Binding Epitopes:}

Data was taken from the Protein Model Portal:

http://www.proteinmodelportal.org/?aid=getModelQualityAnalysis\&sid=PMPSIDB54869D2FC55AF3961DCD7C0CCB714CA\&queryfromto $=0$ 214\&ref ac $=Q 00731$

The structure of murine VEGF-A (UniprotKB identifier Q00731) was compared with that of human VEGFA from the NMR studies with VEGF-v107 complex conducted by Pan et. al (PDB 1KAT). Amino acid sequences of both proteins were aligned and the sequence from 37-134 were compared. Model 1 indicates murine VEGF and $1 \mathrm{katW}$ indicates human VEGF. It is important to note that the v107 peptide binding epitope lies within the 37-134 amino acid sequence. 


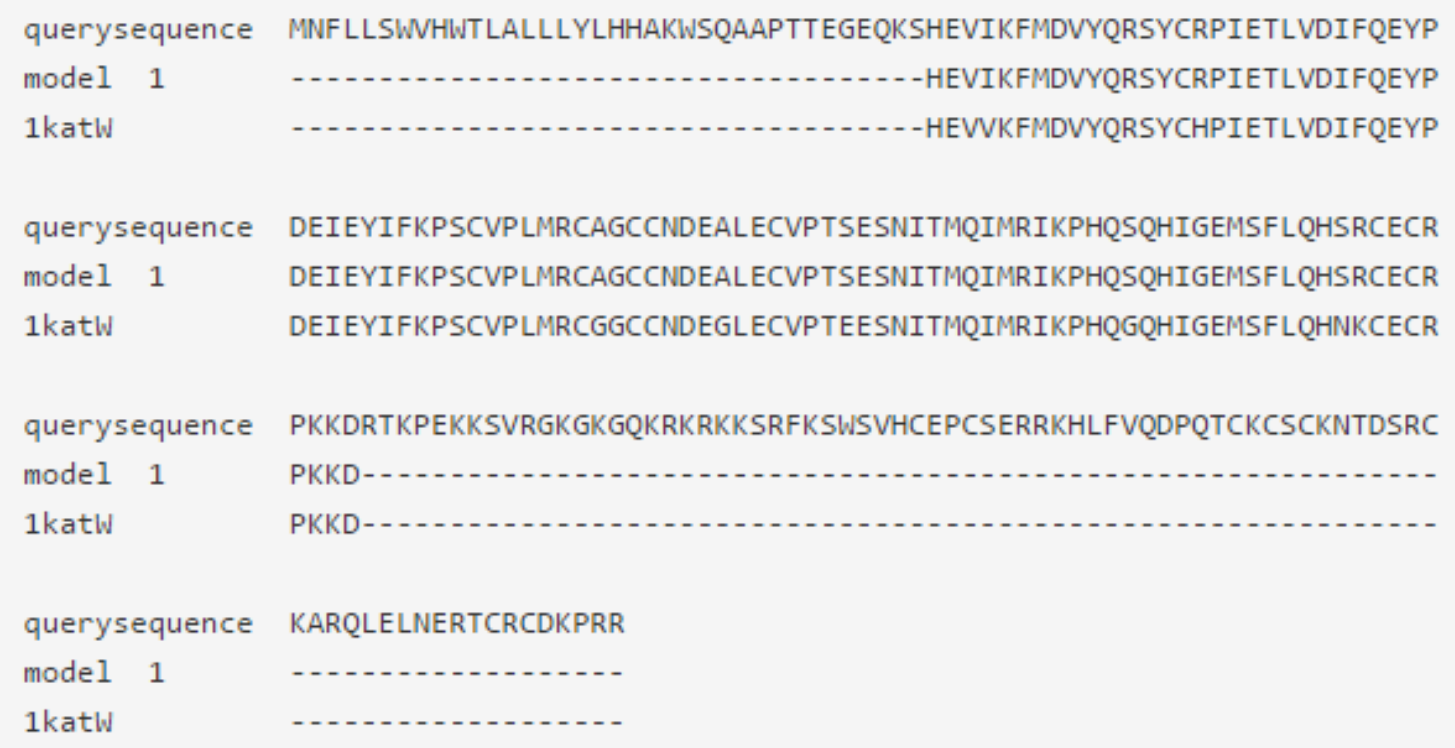

Superposition of Human and Murine VEGF Structures

Human VEGF is depicted in green and murine VEGF in black, showing homology from amino acids 37 134. The arrow points to VEGF Lys-48, an important amino acid for v107 peptide binding.

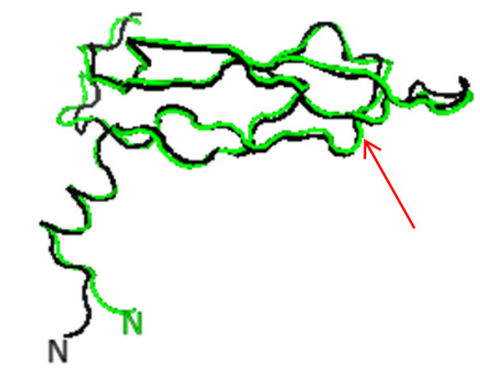

\section{Results of Superposition}

Root mean square deviations (RMSD, in A) based on pairwise superpositions ( $C A$ atoms) onto the model/structure with the highest sequence coverage are listed below.

RMSD of

human VEGF (green) to murine VEGF (black) total RMSD

$1.4 \AA / / 98$ residues
RMSD of final subset

$0.9 \AA / / 95 / 98$ residues 


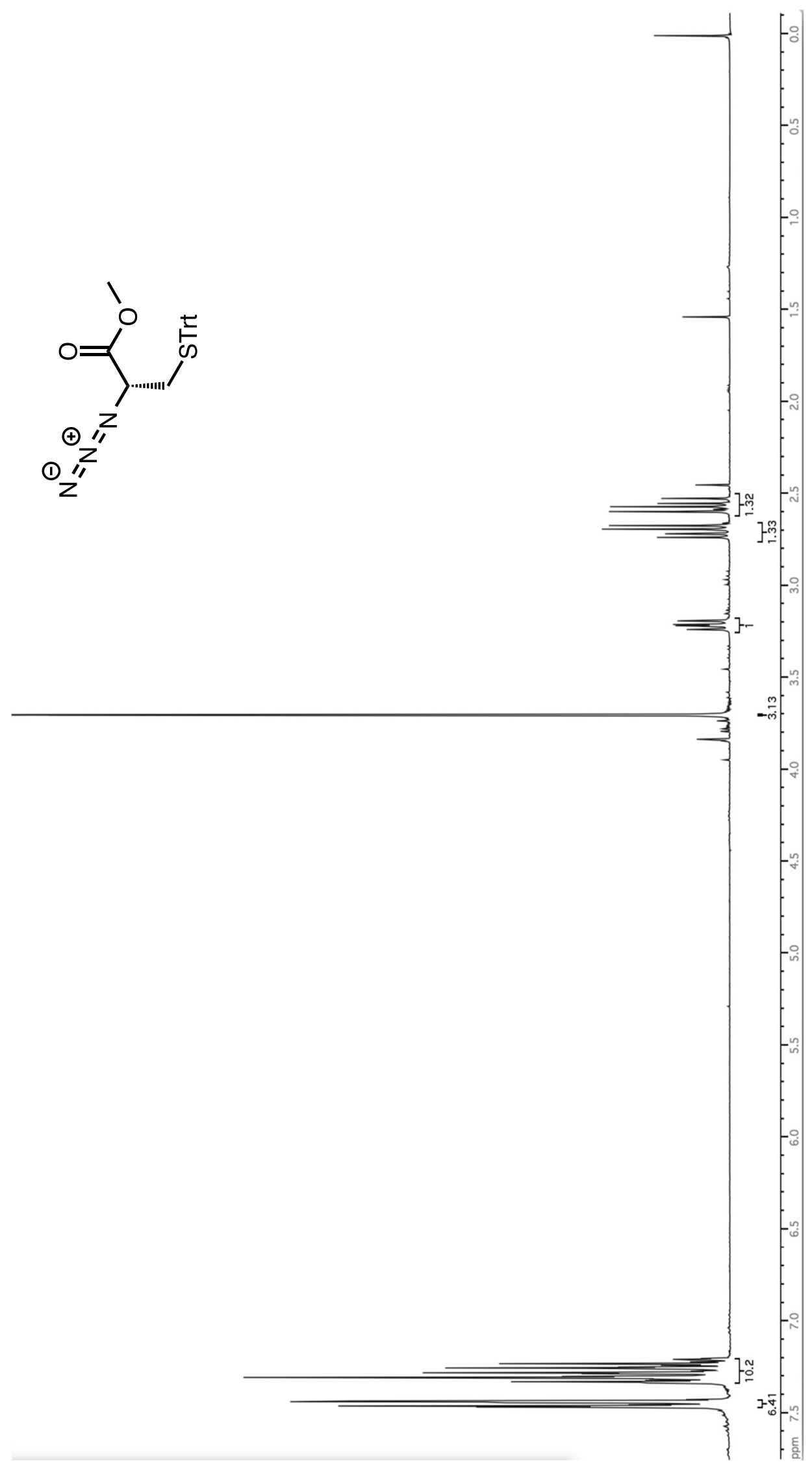




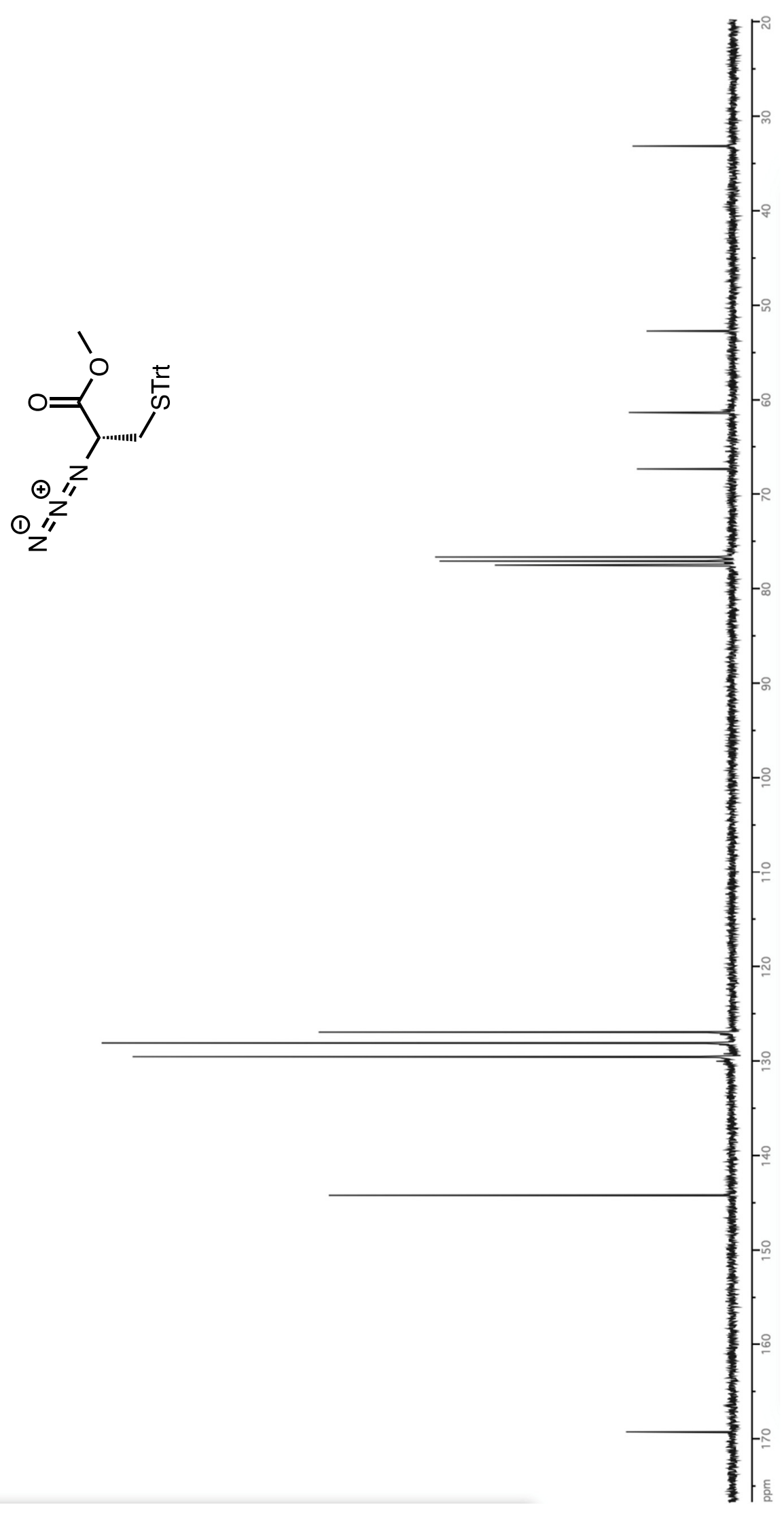




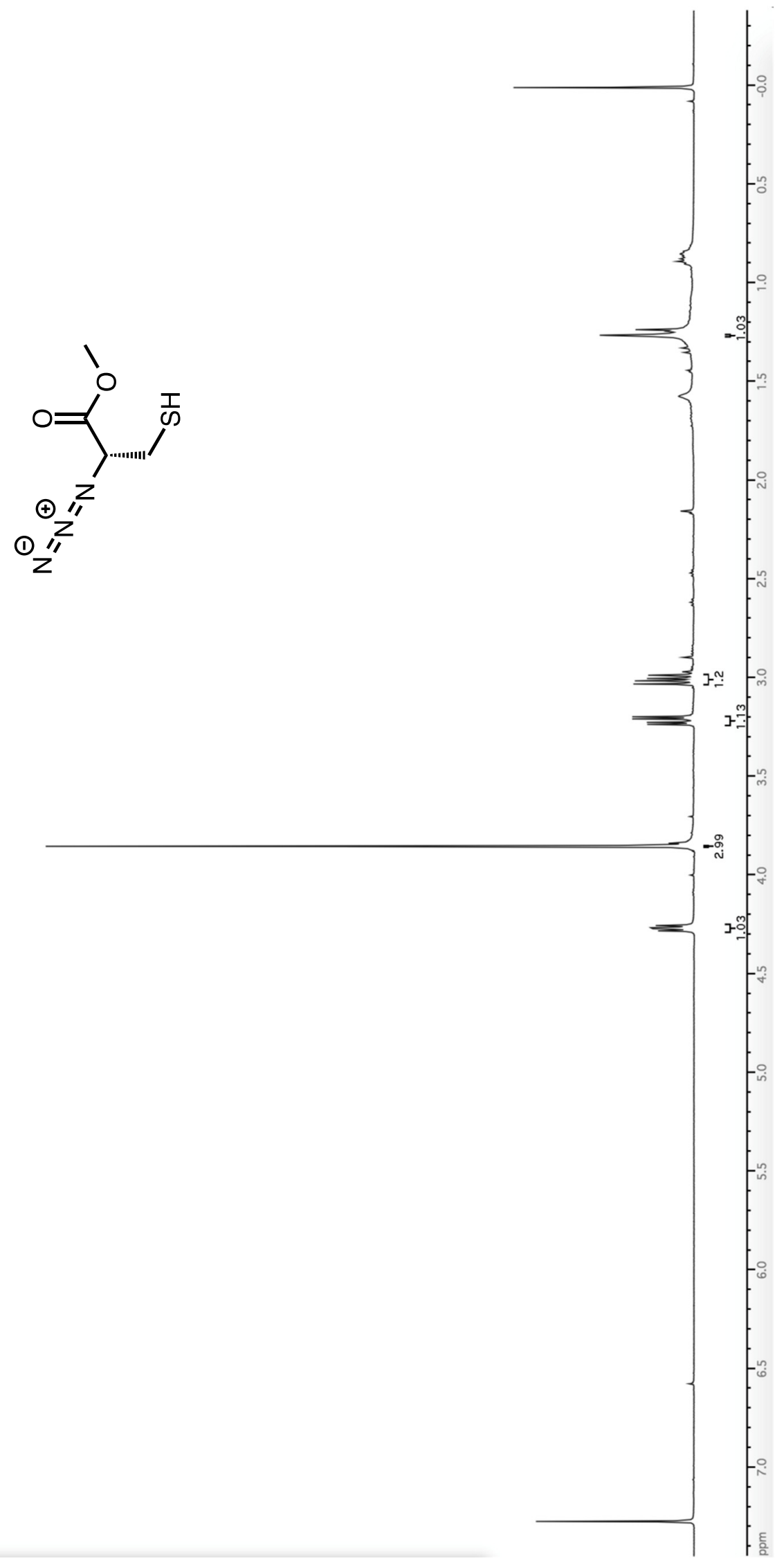



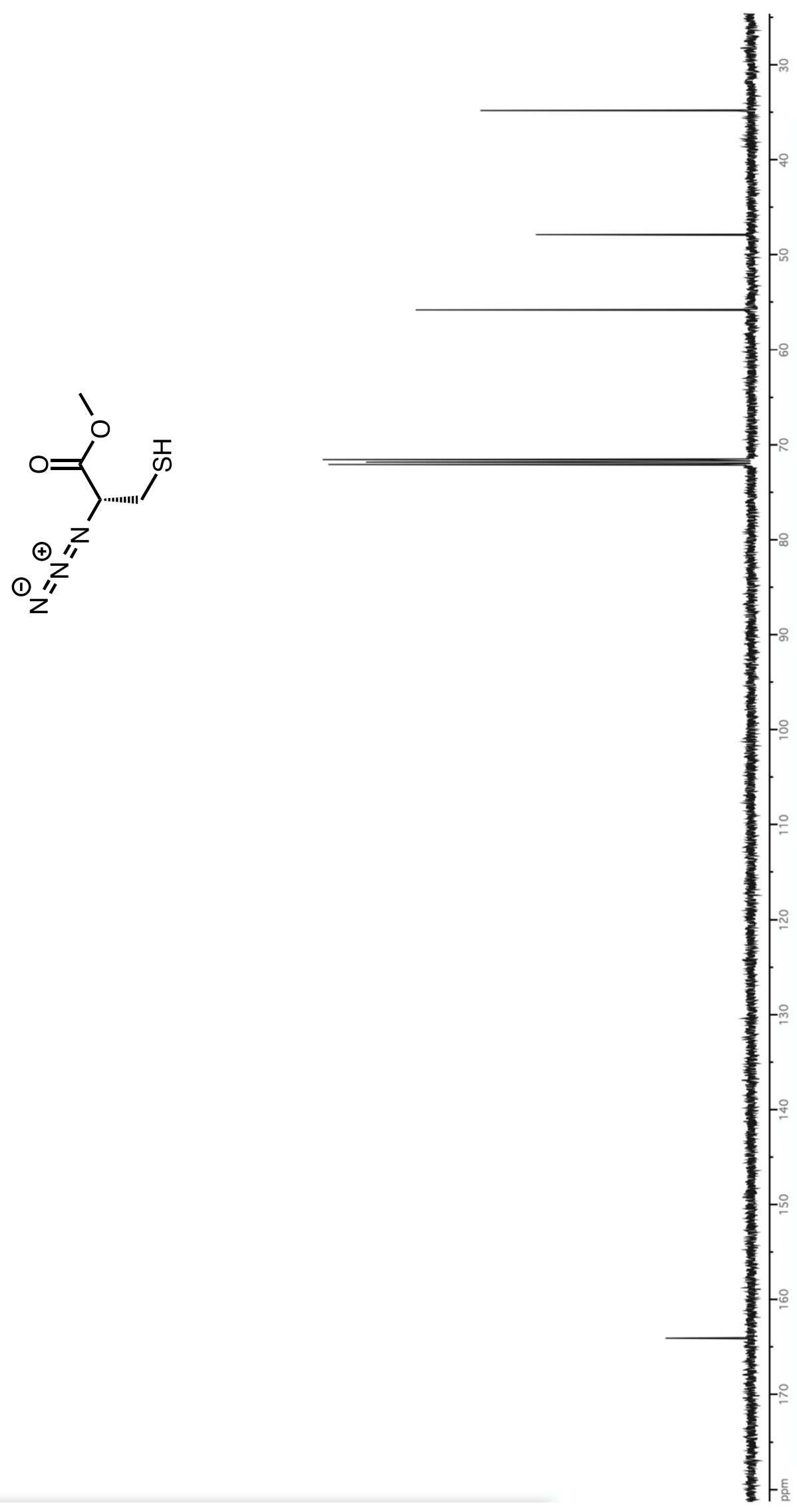


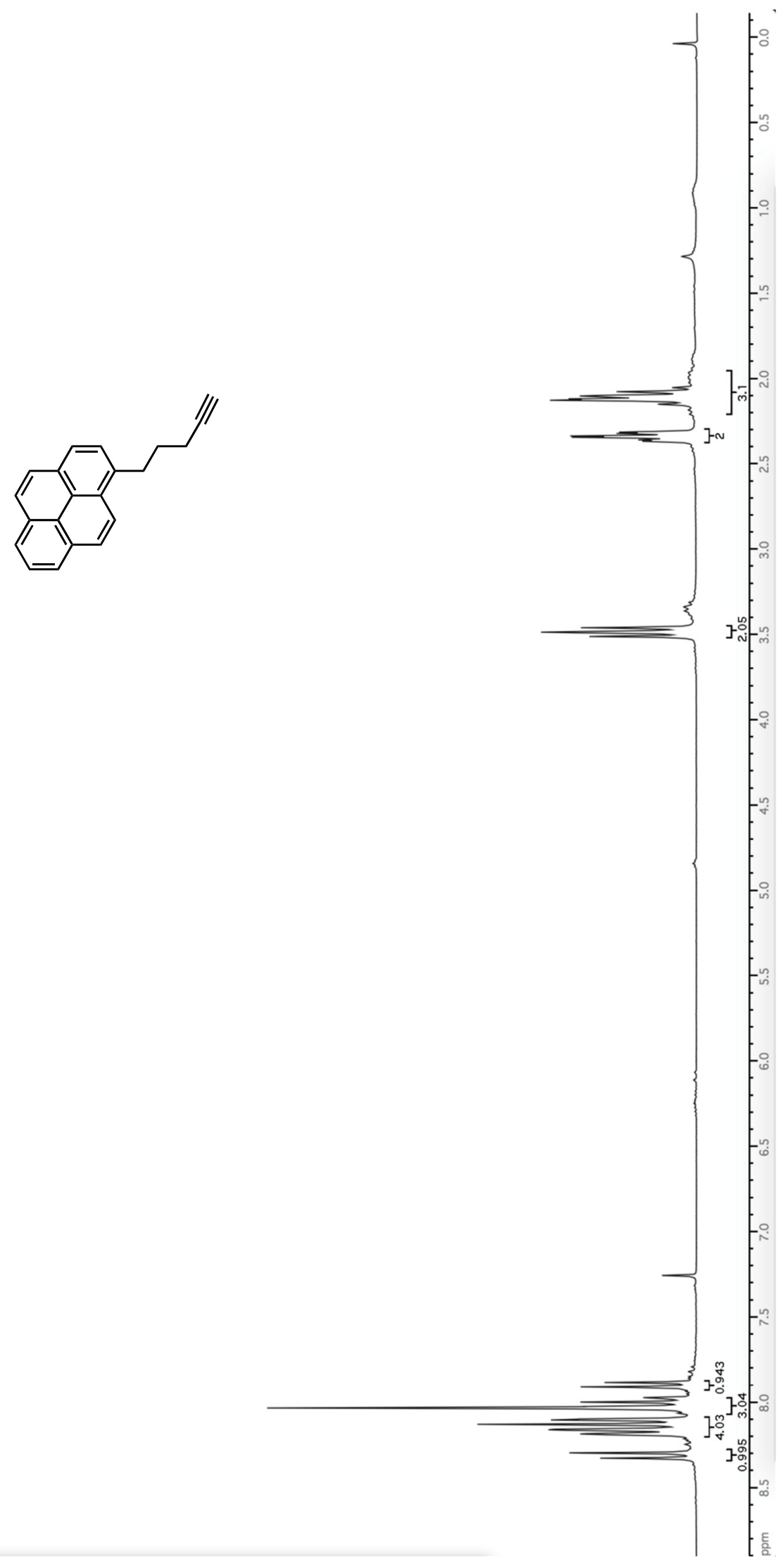




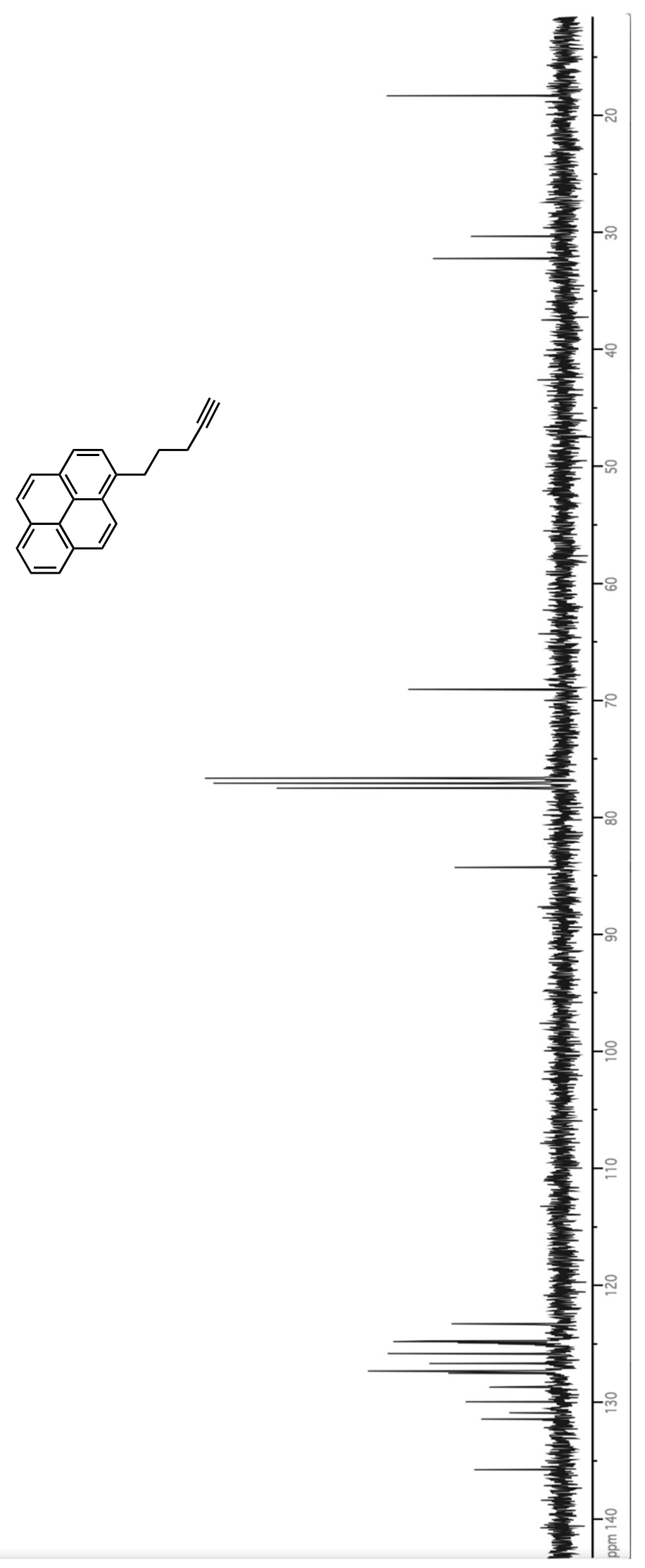

S-10 